\title{
ANIMAL MODELS FOR COLORECTAL CANCER
}

\author{
Modelos animais de carcinogênese colorretal
}

\author{
Alana Serrano Campelo DE-SOUZA ${ }^{1}$, Thais Andrade COSTA-CASAGRANDE ${ }^{1}$
}

\begin{abstract}
How to cite this article: De-Souza ASC, Costa-Casagrande TA. Animal models for colorectal cancer. ABCD Arq Bras Cir Dig. 2018;31(2):e1369.
\end{abstract} DOI: /10.1590/0102-672020180001e1369

From the ${ }^{1}$ Mestrado Profissional em Biotecnologia Industrial, Universidade Positivo (Professional Master'sDegree in Industrial Biotechnology, Positivo University), Curitiba, Paraná,Brazil

\begin{abstract}
HEADINGS - Models, animal. Colorectal neoplasms. Carcinogens.
\end{abstract}

\section{Correspondence:}

Alana Serrano Campelo de-Souza

E-mail: alanaserrano65@gmail.com;

alana_campelo@hotmail.com

Financial source: none

Conflict of interest none

Received for publication: 23/01/2018 Accepted for publication: 27/03/2018

DESCRITORES - Modelos animais Neoplasias colorretais. Carcinógenos.
ABSTRACT - Introduction: Colorectal cancer is a very frequent sort of neoplasm among the population, with a high mortality rate. It develops from an association of genetic and environmental factors, and it is related to multiple cell signaling pathways. Cell cultures and animal models are used in research to reproduce the process of disease development in humans. Of the existing animal models, the most commonly used are animals with tumors induced by chemical agents and genetically modified animals. Objective: To present and synthesize the main animal models of colorectal carcinogenesis used in the research, comparing its advantages and disadvantages. Method: This literature review was performed through the search for scientific articles over the last 18 years in PubMed and Science Direct databases, by using keywords such as "animal models", "colorectal carcinogenesis" and "tumor induction". Results: 1,2-dimethylhydrazine and azoxymethane are carcinogenic agents with high specificity for the small and large intestine regions. Therefore, the two substances are widely used. Concerning the genetically modified animal models, there is a larger number of studies concerning mutations of the $A P C, p 53$ and $K$-ras genes. Animals with the APC gene mutation develop colorectal neoplasms, whereas animals with $p 53$ and $K$-ras genes mutations are able to potentiate the effects of the $A P C$ gene mutation as well as the chemical inducers. Conclusion: Each animal model has advantages and disadvantages, and some are individually efficient as to the induction of carcinogenesis, and in other cases the association of two forms of induction is the best way to obtain representative results of carcinogenesis in humans.
RESUMO - Introdução: O câncer de cólon e reto é bastante frequente na população e com elevado índice de mortalidade. Ele se desenvolve a partir da associação de fatores genéticos e ambientais e está relacionado a múltiplas vias de sinalização celular. Para o estudo da doença são utilizados cultivos celulares e modelos animais, que sejam capazes de reproduzir o processo de desenvolvimento da doença em humanos. Dos modelos existentes, os mais comumente utilizados são os animais induzidos ao desenvolvimento tumoral por agentes químicos e os animais geneticamente modificados. Objetivo: Apresentar e sintetizar os principais modelos animais de carcinogênese colorretal utilizados na pesquisa, comparando suas vantagens e desvantagens.Método: Para o desenvolvimento dessa revisão foi realizada uma busca por artigos científicos dos últimos 18 anos nas bases de dados PubMed e Science Direct, utilizando como palavras-chave "modelos animais", "carcinogênese colorretal" e "indução tumoral". Resultado: 0 1,2 dimetilhidrazina e o azoximetano são agentes carcinógenos com alta especificidade para o intestino delgado e grosso. Por isso, as duas substâncias são amplamente utilizadas. Dos modelos animais geneticamente modificados observa-se maior quantidade de estudos referentes às mutações dos genes $A P C, p 53 \mathrm{e} K$-ras. Os animais com mutação do gene $A P C$ desenvolvem neoplasias colorretais, enquanto que animais com mutações dos genes p53 e $K$-ras são capazes de potencializar os efeitos da mutação do gene $A P C$, bem como dos indutores químicos. Conclusão: Cada modelo animal apresenta vantagens e desvantagens, sendo que alguns são individualmente eficientes na indução da carcinogênese, e em outros casos a associação de duas formas de indução é a melhor maneira de se obter resultados representativos da carcinogênese em humanos.
C ancer is a sort of disease that can reach most of the organs and tissues of the human body. It is characterized primarily by the disordered growth of cells, often able to metastasize to other regions of the body. According to Petit et al. ${ }^{19}$, the disease is associated with both genetic factors, inherent to each individual, and environmental factors.

Colorectal cancer (CRC) is the $4^{\text {th }}$ most frequent neoplasm among the world's population, accounting for 694,000 of the 8.2 million cancer deaths in $2012^{26}$. It is a very aggressive type of cancer that has a high potential to spread to other organs. It develops in $90-95 \%$ of cases due to environmental factors ${ }^{2,14}$ and it is related to multiple signal transduction cascades, important for different types of biological response such as angiogenesis, apoptosis and cell proliferation ${ }^{24,29}$.

CRC may be hereditary or sporadic, accounting for $80 \%$ of all patients affected by the disease. The hereditary form is related to two familial syndromes, familial adenomatous polyposis, in which the appearance of multiple intestinal polyps, 
and hereditary nonpolyposis colorectal cancer is observed. Individuals who develop familial adenomatous polyposis have a mutation in the APC (adenomatous polyposis of the colon) tumor suppressor gene, whereas those who develop hereditary nonpolyposis colorectal cancer have mutations in genes involved in DNA repair and mismatch repair (MMR) genes ${ }^{6}$. The sporadic form, in turn, is related to inflammatory bowel processes such as Crohn's disease and ulcerative colitis, as well as to eating habits such as red meat consumption and low fiber intake ${ }^{12,19}$.

For studies related to the development, treatment and prevention of colon and rectum tumors, animal models or cell cultures, which are representative of a carcinogenic situation in humans, are used. However, in spite of all the ethical conflicts involved in animal experimentation ${ }^{20}$, one of the major disadvantages of cell culture, compared to animal models, is the inability to reproduce metastatic and angiogenesis situations ${ }^{11}$.

For research purposes, the two major animal models of colorectal carcinogenesis are colorectal tumors induced by chemical or environmental agents in rodents, which represent sporadic CRC, and genetically modified mice, which represent the hereditary familial adenomatous polyposis and hereditary non-polyposis colorectal cancer syndromes ${ }^{11}$.

This review aims to present and synthesize the main animal models of colorectal carcinogenesis used in the research, comparing its advantages and disadvantages.

METHOD

For the development of this review, a search for scientific articles over the last 18 years in the PubMed and Science Direct databases was carried out, using keywords such as "animal models", "colorectal neoplasias" and "induced colon cancer". The search resulted in 89 articles, of which 31 were selected as the most relevant for this review.

RESULTS

\section{Colorectal cancer induced by exogenous agents}

According to Andrade et al. ${ }^{3}$ there are several factors capable of increasing the chances of developing colorectal cancer, among them the intake of foods rich in fat, and with low fiber content. Thus, the eating habits of an individual can directly influence the occurrence of this neoplasia ${ }^{3}$. Newmark et al. ${ }^{17}$ observed that $25 \%$ of the animals fed for two years on this diet had invasive adenocarcinomas in small bowel, cecum and proximal colon regions; and that another group, fed with a diet enriched with calcium and vitamin $D_{\text {, }}$ did not present intestinal lesions. In addition, Yang et al. ${ }^{28}$ observed that $75 \%$ of the animals, treated for a year and a half with the same lipid diet, had the APC-/+ mutation and $57 \%$ the Muc2-/- mutation, which are important in CRC development. However, only $27 \%$ of them had alterations in the intestinal mucosa.The two studies showed that diet can directly influence the appearance of colorectal neoplasias, as it promotes reprogramming of intestinal cells, thus representing the spontaneous colorectal cancer model in humans. However, although the authors observed different intestinal neoformations in the animals treated with the hyper caloric diet, it was not possible to evaluate which mutations were responsible for the development of the tumors. Also, the diet may not be considered the best model of colorectal carcinogenesis, since the percentage of animals that develop the neoplasia is small, and the time for this to occur is long.

Besides the diet, chemical substances with carcinogenic potential are also used. The two most commonly used tumor inducers in animal models for induction of sporadic CRC are azoxymethane (AOM), which is a direct inducer, and 1,2 dimethylhydrazine $(\mathrm{DMH})$, which is an indirect inducer of carcinogenesis. They are able to represent the mechanisms of development of CRC that occur naturally in humans, being very useful models in studies that aim to study chemopreventive and chemotherapeutic effects of other substances ${ }^{18}$.

$\mathrm{DMH}$ is a pro-carcinogenic agent for colon cancer, it is activated in the liver and transported to the intestine by bile and blood. Its use promotes the production of free radicals, which are responsible for causing oxidative damage to the DNA of colon and liver cells ${ }^{23}$.

According to Burlamaqui et al. ${ }^{4}, \mathrm{AOM}$ is an active metabolite of DMH also used for tumor induction in rodents. It mainly affects organs such as the liver, the lungs and the colon, and the lesions found are directly proportional to time of exposure and the dose administered ${ }^{13}$.

In 2014, Lahouar et al. ${ }^{13}$ using AOM as an inducer, observed that animals in the AOM group had significantly more aberrant crypts, which are pre-neoplastic lesions, than the animals in the control group. In addition, they also noticed the appearance of inflammatory lesions and histological changes in the hepatic and pulmonary tissues of the animals. By 2015, Yu et al. ${ }^{31}$, in addition to observing pre-neoplastic lesions in mice treated with $A O M$, also observed a $51 \%$ and $46 \%$ increase in pro-inflammatory cytokines, such as tumor necrosis factor alpha (TNF-a) and interleukin 6 (IL-6), respectively.

Aachary et al. ${ }^{1}$ observed that animals treated with DMH developed outbreaks of aberrant crypts and also presented alterations in the intestinal microbiota. When compared to the control group, they showed a reduction in the number of Bifidobacteria and an increase in $E$. coli and $C$. perfringens species.

Umesalma and Sudhandiran ${ }^{25}$ demonstrated that animals treated with $\mathrm{DMH}$ showed an increased expression of inflammatory markers cycloxigenase 2 (cox-2) and IL-6. The control group presented $0.6 \%$ and $1.4 \%$ of cells expressing the two markers, respectively, and the DMH group presented $1.2 \%$ and $3.5 \%$ expressions.

$\mathrm{DMH}$ was also effective in CRC induction in a study by Youssef et al. ${ }^{30}$ which detected about 100.5 aberrant crypts foci in the 10 animals that received the inducer, and a total of 20 colorectal tumors in these same individuals, whereas the animals in the control group had neither pre-neoplastic lesions nor neoformations.

Both substances are used for CRC induction in rodents. However, there is controversy over which of the two is the most effective in tumor induction. Burlamaqui et al. ${ }^{4}$ stated that $\mathrm{AOM}$ is a more potent inducer than $\mathrm{DMH}$ because it is activated faster in the body. However, in a comparative study done by Jucá et al. ${ }^{12}$ it was observed that the induction by $\mathrm{DMH}$ promoted the appearance of dysplasias in mild, moderate and severe degree, in addition to carcinomas in situ, whereas the induction by AOM promoted only moderate dysplasia in the colon of the animals.

Since $\mathrm{AOM}$ is an active metabolite of $\mathrm{DMH}$, the mechanism of induction of carcinogenesis promoted by the two substances is very similar. In the studies mentioned, the formation of aberrant crypts foci and intestinal inflammatory processes was observed in the animals treated with both $\mathrm{DMH}$ and AOM. However, DMH seems to be a more effective agent because in addition to the pre-neoplastic and inflammatory lesions, it also promoted the development of intestinal adenomas and carcinomas. Thus, from the models induced by exogenous agents it can be concluded that all agents, diet, AOM and DMH are able to induce CRC. But the diet proves to be a slow and low-efficiency model; the AOM is an inducer of mainly aberrant crypts foci and inflammation, and 
$\mathrm{DMH}$ is an inducer of colorectal tumors in more advanced stages, showing to be the most efficient model.

\section{Genetically modified animals}

Many genes are involved in colorectal carcinogenesis, including tumor suppressors $A P C, D C C$ (deleted in colorectal cancer), p53 (gene encoding tumor protein p53) and MCC (mutated in colorectal cancer), the oncogenes $K$-ras(Kirsten rat sarcoma viral oncogene homolog), SRC(proto-oncogene SRC) and C-myc (homologous oncogene viral myelocytomatosis), the DNA repair genes $h M S H 2$ (mutS 2 homologue), hMSH6 (mutS 6 homologue), hMLH1 (mutL 1 homologue), hPMS 1 (BstNIproline rich protein subfamily 1 ) and hPMS2 (BstN1 proline rich protein subfamily 2 ), in addition to CD44 genes (gene encoding CD44 molecule) and COX-2 (cytochrome C oxidase, subunit 2). Each of them acts differently for the development of colorectal neoplasms, and mutations in two or more of these genes are often related to the malignancy profile of the tumors ${ }^{6}$.

Thus, there are innumerable genetically modified animal models that have been developed from the knowledge about the genetic factors involved in the development of the disease ${ }^{6}$. However, only the models whose mutations are most frequent in sporadic CRC in humans (APC> 70\%, $p 53>60 \%$ and $K$-ras $>40 \%$ ) and in hereditary familial adenomatous polyposis $(A P C)$ and hereditary nonpolyposis colorectal cancer $(M M R)^{11}$ will be described next.

$A P C^{\text {min }}$ animals are genetically modified that have a mutation in the APC gene. The acronym "min" means multiple intestinal neoplasms, and this is an autosomal dominant mutation, which in homozygous conditions is lethal to animals. Animals that are heterozygous for the mutation develop important anemic conditions at 60 days of life and develop tumors in the large and small intestine. As in familial adenomatous polyposis cases, $A P C^{\mathrm{min}}$ animals also develop colorectal adenomas, but they die at 120 days of life ${ }^{27}$.

Knockout animals for $p 53$ gene rarely develop colorectal tumors. Reed et al. ${ }^{21}$ reported in 2008 that $p 53$ knockout animals did not develop colorectal neoplasias; however, the association of $A P C^{\mathrm{min}}$ and $p 53$ knockout mutations promoted an increase in aberrant crypts foci number when compared to $A P C^{\text {min }}$ animals. In addition, in $2008 \mathrm{Hu}$ et al. ${ }^{10}$ reported that an association of $p 53$ knockout animals with tumor inducer AOM was efficient in inducing carcinogenesis in the colon of the animals, and also to potentiate the action of the AOM. The same could be observed by Sakai et al. ${ }^{22}$ in which p53 knockout animals showed only neoplastic development when placed in contact with the $\mathrm{DMH}$ inducer.

In addition to animals with mutations in the APCand p53genes, mice with mutations in codon 12 of the $K$-ras gene are also used. From a homologous recombination process, one of the $K$-ras gene alleles is replaced by a mutated $K$-ras ${ }^{\mathrm{G} 12 \mathrm{D}}$ allele in which there is the substitution of a guanine with an adenine at the second base of codon 8 . According to Haigis et al. ${ }^{9}$ animals with this mutation have regions of hyperplasia in the colon as well as aberrant crypt and ring cells. Associating the $K-$ ras $^{\mathrm{G} 12 \mathrm{D}}$ and $A P C^{\mathrm{min}}$ mutations, Calcagno et al. ${ }^{5}$ and Luo et al ${ }^{16}$ reported an increase in the number of lesions in the colon, as well as the presence of completely undifferentiated cells.

Another mutation found in colorectal tumors is the $K$-ras ${ }^{12}$ mutation, in which the substitution of a guanine for a thymine occurs. In 2007, Luo et al. ${ }^{15}$ demonstrated that the $K-$ ras $^{v 12}$ mutation alone is not capable of inducing tumorigenesis, but once it is associated with mutations in repair genes, such as the MSH2 gene, it promotes and accelerates tumor development. $K$-ras ${ }^{v 12} / M s h 2-/-$ animals presented a greater number of tumors, both in the small and in the large intestine, than Msh2-/- animals: ranging from 1.41 to 7.75 tumors per mouse in the small intestine and from 0.13 to 2.7 tumors per rat in the large intestine.

These mutations in DNA repair genes are representative of hereditary nonpolyposis colorectal cancer. According to Edelmann et al. ${ }^{7} 7 / 22$ (32\%) mice $M L H 1+/-$ and $13 / 18$ (72\%) of $M L H 1-/-$ mice developed tumors, against 1/20 (5\%) mice without the mutation. In addition, they also observed that the survival of animals was lower in MLH1-/- animals than in $M L H 1+/-, 7$ and 9.8 months, respectively,

Among the genetically modified models, the one that best represents the hereditary $C R C$ are the $A P C^{\text {min }}$ animals, among which the formation of intestinal tumors is observed. The other mutants only become representative models when an association of two or more types of mutation is made, or through the association of a mutation with induction by an exogenous agent, such as diet, for example. All models presented, both induced by exogenous agents and those genetically modified, have advantages and disadvantages (Table 1) for the study of colorectal carcinogenesis. However, some of them, such as tumor induction by DMH and $A P C^{\min }$ animals, are more suitable for research because of their ability to develop colorectal neoplasias, without the need to associate two or more induction methods.

TABLE 1 - Animal models used for research in colorectal cancer, and their main advantages and disadvantages

\begin{tabular}{|c|c|c|c|c|}
\hline $\begin{array}{l}\text { Animal } \\
\text { Model }\end{array}$ & CRC type & Advantages & Disadvantages & References \\
\hline $\begin{array}{l}\text { Western } \\
\text { Diet }\end{array}$ & Sporadic & $\begin{array}{l}\text { Induction of carcinogenesis in small } \\
\text { intestine, cecum and proximal colon. }\end{array}$ & $\begin{array}{l}\text { Dietary mutations have not been described yet. } \\
\text { Few animals develop neoplastic lesions and the } \\
\text { time of development is rather long. }\end{array}$ & 17,28 \\
\hline $\mathrm{DMH}$ & Sporadic & $\begin{array}{l}\text { Capacity to induce metastasis. } \\
\text { Induction of adenomas and } \\
\text { adenocarcinomas. } \\
\text { High degree of specificity for intestine. }\end{array}$ & $\begin{array}{l}\text { Indirect inducer. } \\
\text { Promotes liver toxicity. }\end{array}$ & 23 \\
\hline $\mathrm{AOM}$ & Sporadic & $\begin{array}{l}\text { Direct inducer. } \\
\text { High degree of specificity for intestine. }\end{array}$ & $\begin{array}{l}\text { More expensive than DMH. } \\
\text { Promotes liver toxicity. }\end{array}$ & 4 \\
\hline APC & $\begin{array}{l}\text { SporadicandHereditary } \\
\text { (PAF) }\end{array}$ & Good for study of hereditary CRC. & Animals die within 120 days. & 27 \\
\hline P53 & Sporadic & $\begin{array}{l}\text { It potentiates the action of other genes or } \\
\text { tumor inducers. }\end{array}$ & $\begin{array}{l}\text { Inhibition of gene expression alone was not able } \\
\text { to induce colorectal carcinogenesis. }\end{array}$ & 21 \\
\hline K-ras & Sporadic & $\begin{array}{c}\text { Hyperplasia and presence of aberrant crypts. } \\
\text { It potentiates tumorigenesis of other } \\
\text { mutations. }\end{array}$ & $\begin{array}{l}\text { They do not develop tumors, only pre-neoplastic } \\
\text { lesions. Association with other mutations and/or } \\
\text { inducers is required. }\end{array}$ & 9,15 \\
\hline MMR & Hereditary (HNPCC) & Good for study of hereditary CRC (HNPCC). & Most tumors are in the small intestine. & 7,15 \\
\hline
\end{tabular}




\section{DISCUSSION}

Animal models are important for studies of the development and pathogenesis of colorectal tumors, as well as for the evaluation of possible risk factors, preventive agents and treatments. As shown, some individual models are representative of CRC in humans and considered to be good animal models for this type of study. However, it is noted that the association of at least two methods of colorectal carcinogenesis induction is required for most models. This is due to the fact that colon cancer is a multifactorial disease that develops by the presence of multiple factors, both genetic and environmental.

\section{CONCLUSION}

Each animal model has advantages and disadvantages, and some models are individually efficient as to the induction of carcinogenesis, and in other cases the association of two forms of induction is the best way to obtain representative results of carcinogenesis in humans.

\section{REFERENCES}

1. Aachary AA, Gobinath D, Srinivasan K, Prapulla SG. Protective effect of xylooligosaccharides from corncob on 1,2-dimethylhydrazine induced colon cancer in rats. Bioact Carbohydrates Diet Fibre [Internet]. Elsevier 2015;5(2):146-52.Availablefrom:http://dx.doi.org/10.1016/j.bcdf.2015.03.004

2. Anand $P$, Kunnumakkara $A B$, Sundaram $C$, Harikumar $K B$, Tharakan $S T$, Lai OS, Sung B, Aggarwal BB. Cancer is a preventable disease that requires major lifestyle changes. Pharm Res. 2008;25:2097-2116.

3. Andrade PO, Bitar RA, Yassoyama K, Martinho H, Santo AME, Bruno PM, et al. Study of normal colorectal tissue by FT-Raman spectroscopy. Anal Bioanal Chem. 2007;387(5):1643-8.

4. Burlamaqui IMB, Dornelas CA, Almeida PRC, Jamacaru FVF, Mota DMC, Mesquita FJC, De Brito LA, Veras LB, Rodrigues LV. Repercussão hepática da carcinogênese colorretal induzida pelo azoximetano. RevColBras Cir. 2013;40:137-141.

5. Calcagno SR, LiS, Colon M, Kreinest PA, Thompson EA, Fields AP, Murray NR. Oncogenic Kraspromotesearlycarcinogenesisinthemouse proximal colon. Int J Cancer. 2008;122:2462- 2470.

6. Cotti GCC, Pires FPS, Sebastianes FM, Habr-Gama A, Seid VE, Martino RB. Genética do câncer colorretal. Rev Med. 2000;79:45-64.

7. Edelmann W, Yang F, Kuraguchi M, Heyer J, Lia M, Kneitz B, Fan KH Brown AMC, Lipkin M, Kucherlapati R. Tumorigenesis in Mlh1 and Mlh1/ Apc1638N mutantmice. Cancer Research. 1999; 59:1301-1307.

8. Fearon ER. Molecular genetics of colorectal cancer. Annu Rev Pathol. 2011;6:479-507

9. Haigis KM, Kendall KR, Wang $Y$, Cheung A, Haigis MC, Glickman JN, Niwa-Kawakita M, Sweet-Cordero A, Sebolt-Leopold J, Shannon KM Settleman J, Giovannini M, Jacks T. Differential effects of oncogenic $\mathrm{K}$-Ras and N-Ras on proliferation, differentiation and tumor progression in the colon. Nat Genet. 2008:40:600-608.

10. HuY, Le Leu RK, Belobrajdic D, Young GP. The potential of sphingomyelin as a chemopreventive agent in AOM-induced colon cancer model: wildtype and p53+/- mice. MolNutr Food Res. 2008;52:558-566.

11. JohnsonRL,FleetJC.Animal ModelsofColorectal Cancer.CancerMetastasis Rev. 2013:32(0):39-61.

12. Jucá MJ, Bandeira BC, Carvalho DS, Leal AT. Comparative study of 1,2-dimethylhydrazine and azoxymethane on the induction of colorectal cancer in rats. J Coloproctology [Internet]. Sociedade Brasileira de Coloproctologia;2014;34(3):167-73.Availablefrom:http://www.sciencedirect. com/science/article/pii/S2237936314000550
13. Lahouar L, Ghrairi F, Arem A El, Sghaeir W, Felah M El, Salem H Ben, et al. Attenuation of histopathological alterations of colon, liver and lung by dietary fibre of barley Rihane in azoxymethane-treated rats. Food Chem [Internet]. Elsevier Ltd; 2014;149:271-6. Available from: http:// dx.doi.org/10.1016/j.foodchem.2013.10.101L.

14. LiY-H, NiuY-B, Sun Y, Zhang F, Liu C-X, Fan L, etal. Role of phytochemicals in colorectal cancer prevention. World J Gastroenterol [Internet]. 2015;21(31):9262-72.Availablefrom:http://www.pubmedcentral.nih.gov/ articlerender.fcgi?artid $=4541379 \&$ tool=pmcentrez\&rendertype $=$ abstract

15. Luo F, Brooks DG, Ye H, Hamoudi R, Poulogiannis G, Patek CE, Winton DJ Arends MJ.Conditional expression ofmutated K-rasacceleratesintestinal tumorigenesis in Msh2-deficient mice. Oncogene. 2007 26:4415-4427.

16. Luo F, Brooks DG, Ye H, Hamoudi R, Poulogiannis G, Patek CE, Winton DJ, Arends MJ. Mutated K-ras(Asp12) promotes tumorigenesis in Apc(Min) mice more in the large than the small intestines, with synergistic effects between K-ras and Wnt pathways. Int J ExpPathol. 2009:90:558-574.

17. Newmark HL, Yang K, Kurihara N, Fan K, Augenlicht LH, Lipkin M. Western-style diet-induced colonic tumors and their modulation by calcium and vitamin D in C57BI/6 mice: a preclinical model for human sporadic colon cancer. Carcinogenesis. 2009;30:88-92.

18. Perse M, Cerar A. Morphological and molecular alterations in 1,2 dimethylhydrazine and azoxymethane induced colon carcinogenesis in rats. J Biomed Biotechnol. 2011;2011:1-14.

19. Petit C, Oswald E, Nougayrede JP. Role des genotoxinesproduites par des bacteries du microbiotedans le cancer colorectal. Rev Francoph des Lab [Internet]. Elsevier; 2013(456):77-82. Available from: http://dx.doi. org/10.1016/S1773-035X(13)72226-3

20. Raymundo MM, Goldim JR. Ética Da Pesquisa Em Modelos Animais. Rev Bioética. 2002;10(1):31-44.

21. Reed KR, Meniel VS, Marsh V, Cole A, Sansom OJ, Clarke AR. A limited role for p53 in modulating the immediate phenotype of Apc loss in the intestine. BMC Cancer. 2008;8:1-9. doi: 10.1186/1471-2407-8-162.

22. Sakai H, Tsukamoto T, Yamamoto M, Shirai N, lidaka T, Hirata A, YanaiT, MasegiT, DonehowerLA, Tatematsu M. High susceptibility of nullizygous p53knockoutmicetocolorectaltumorinduction by 1,2-dimethylhydrazine. J Cancer Res ClinOncol. 2003;129:335-340.

23. Shih CK, Ho CJ, Li SC, Yang SH, Hou WC, Cheng HH. Preventive effects of rice bran oil on 1,2-dimethylhydrazine/dextran sodium sulphateinduced colon carcinogenesis in rats. Food Chem [Internet]. Elsevier Ltd; 2011;126(2):562-7. Available from: http://dx.doi.org/10.1016/j. foodchem.2010.11.043

24. Subramaniam A, Shanmugam MK, Perumal E, Li F, Nachiyappan A, DaiX, Swamy SN, Ahn KS, Kumar AP, Tan BK, Hui KM, Sethi G. Potential role of signal transducerand activator of transcription(STAT)3 signaling pathway in inflammation, survival, proliferation and invasion of hepatocellular carcinoma. BiochimBiophysActa. 2013;1832:46-60.

25. UmesalmaS, SudhandiranG.Differentialinhibitoryeffectsofthepolyphenol ellagic acid on inflammatory mediators NF-?B, iNOS, COX-2, TNF-a, and IL-6 in 1,2-dimethylhydrazine-induced rat colon carcinogenesis. Basic ClinPharmacolToxicol. 2010;107(2):650-5.

26. World Health Organization (WHO). Câncer. http://www.who.int/ mediacentre/factsheets/fs297/en/ (acessoem 28.04.2015).

27. Yamada Y, Mori H. Multistep carcinogenesis of the colon in Apc(Min/+) mouse. Cancer Sci. 2007:98:6-10.

28. Yang K, Kurihara N, Fan K, Newmark H, Rigas B, Bancroft L, Corner G, Livote E, Lesser M, Edelmann W, Velcich A, Lipkin M, Augenlicht L. Dietary induction of colonic tumors in a mouse model of sporadic colon cancer. Cancer Res. 2008;68:7803-10.

29. Yang CL, Liu YY, Ma YG, Xue YX, Liu DG, Ren Y, Liu XB, LiY, Li Z. Curcumin Blocks Small Cell Lung Cancer Cells Migration, Invasion, Angiogenesis, Cell Cycleand Neoplasiathrough Janus Kinase-STAT3Signalling Pathway. PLoS One. 2012;7:1-12.

30. Youssef KM, Ezzo AM, El-Sayed MI, Hazzaa AA, EL-Medany AH, Arafa M. Chemopreventive effects of curcumin analogs in $\mathrm{DMH}$-Induced colon cancer in albino rats model. Futur J Pharm Sci [Internet]. Elsevier Ltd 2015;1(2):57-72.Availablefrom: http://www.sciencedirect.com/science/ article/pii/S2314724515300273

31. Yu C, Wen XD, Zhang Z, Zhang CF, Wu XH, Martin A, et al. American ginsengattenuatesazoxymethane/dextransodiumsulfate-induced colon carcinogenesisinmice.J Ginseng Res[Internet]. ElsevierLtd;2015;39(1):1421. Available from: http://dx.doi.org/10.1016/j.jgr.2014.07.001 